\title{
The Attribute Assessment Process in the Faculty OF ENGINEERING AT THE UNIVERSITY OF MANITOBA: YEAR THREE
}

\author{
Jillian Seniuk Cicek, Sandra Ingram and Nariman Sepehri \\ Faculty of Engineering, University of Manitoba, Winnipeg, MB, Canada R3T 5V6 \\ umseniuk@myumanitoba.ca
}

\begin{abstract}
This paper describes the third year of a study at the University of Manitoba aimed at exploring how the Canadian Engineering Accreditation Board (CEAB) graduate attributes are manifested and measured in the Faculty of Engineering's curriculum. Instructors from the Departments of Biosystems, Civil, Electrical and Computer, and Mechanical Engineering were asked to consider the presence of four attributes and their subsequent indicators in one engineering course taught in the 2013-14 academic year. The attributes were: A Knowledge Base for Engineering, Individual and Team Work, Impact of Engineering on Society and the Environment, and Economics and Project Management. Data were gathered using a self-administered checklist, which was introduced to instructors in a workshop setting. The checklist has evolved over the three years in an effort to define student attribute competency levels and to create an assessment tool that meets the needs of both the researchers and the instructors, as we work together to examine the graduate attributes in our courses and implement an outcomes-based assessment protocol. The data from this third year give us the ability to report on how the remaining four CEAB graduate attributes are presently manifest and measured in our engineering faculty, to look for evidence of outcomes-based assessment, to evaluate the checklist as an assessment tool, and to reflect on the overall process.
\end{abstract}

Keywords: CEAB graduate attributes; outcomes-based assessment; accreditation; instructor checklist

\section{INTRODUCTION}

As part of accreditation, engineering faculties across Canada are required to assess the 12 Canadian Engineering Accreditation Board (CEAB) graduate attributes. These attributes can be considered competencies, or the knowledge, skills, behaviors, attitudes and values [17][18] that are intended to prepare engineering graduates more completely for employment [16], particularly in a profession that has become increasingly global [6]. Five of the attributes are often considered the "traditional" competencies, and seven considered the "professional" [23] or higher-order competencies [2].

Due to the fact that these competencies are the graduate attributes, the higher-level courses, such as those found in third and fourth year engineering, and specifically the capstone courses, are ideal for assessing these aptitudes in students [2][3]. Professional attributes such as Impact of Engineering on Society and the Environment, Individual and Team Work, Economics and Project Management are particularly characteristic of capstone conceptual design projects: "the design project provides an opportunity to assess many of the higher order skills that graduates of a university degree program are expected to possess" [2]. Similarly, in addition to assessing students, it is also productive to map where these attributes are located across the curriculum, and determine how they are manifest and measured in individual courses. These data can be used to develop and improve engineering programs to ensure that they are furnished to cultivate the defined attributes in their students.

Three years ago, in the Faculty of Engineering at the University of Manitoba, a study was initiated to explore how the $12 \mathrm{CEAB}$ graduate attributes were manifest and measured in the engineering curriculum [10][19][20]. The objectives of the study were to: (i) investigate how the CEAB attributes manifest in the curriculum; (ii) reflect on how they are measured; (iii) explore what instructors determine as the level that represents student competency for each attribute/indicator; and (iv) explore the extent to which the measurable attributes result in course content proficiency [10][19][20]. The data were gathered using a checklist that instructors from the four engineering programs - Biosystems, Civil, Electrical and Computer, and Mechanical engineering - self-administered. Data were collected two times throughout the academic year, during the Fall and Winter semesters.

For each year of the study, four new attributes were chosen, ensuring that there was a selection of both the traditional and professional competencies. For the third 
year, the remaining attributes represented one traditional and three professional competencies: A Knowledge Base for Engineering; Individual and Team Work; Impact of Engineering on Society and the Environment; and Economics and Project Management. In this paper, the data collected from the Fall 2013 portion of the year are presented, the evidence of outcomes-based assessment is discussed, the checklist is evaluated as an assessment tool, and the researchers reflect on the overall process.

\section{METHODS}

For the third year of the faculty attribute assessment study, the four attributes, A Knowledge Base for Engineering, Individual and Team Work, Impact of Engineering on Society and the Environment, and Economics and Project Management and their associated foci and indicators were built into the checklist administered during the 2013-14 academic year. A selection of instructors who had not participated in the study before and were chosen by their program department heads, were asked to report the extent to which the indicators for each attribute were built into their course and its associated mark distribution (Full, Part, None). If the indicator was marked as Full, then instructors were asked to record the assessment tools, assessment communication and the expected competency level and target percentage for the indicator (see Appendix A).

There were four changes made to the checklist for the third year of the study, including amendments to the language; the reporting categories; the structure; and the directions (see Appendix A). As well, the process by which the checklist was introduced to instructors was modified.

Firstly, the language was adjusted for clarity, as well as to further reflect wording characterized by outcomesbased assessment. For example, "Evaluation Tools" was changed to "Assessment Tools," "Forms of Communication" became "Assessment Communication" and "Level that Indicates Competency" was expressed as "Expected Competency Level." Changes were also made to the directions (both wording and layout) to further clarify what researchers intended instructors to report on. This was deemed important due to some of the confusion experienced by the instructors during the previous years of the study [10][19][20].

Secondly, one reporting category was expanded. "Target Percentage" was added to "Expected Competency Level." This was done to not only support instructors to think about and report on what level of knowledge, skill or behavior they intended their students to exemplify, but to also encourage instructors to set a goal for the number of students in the class whom they felt should perform at this level. This was proposed to add another layer to the process of outcomes-based assessment for the purposes of program development and improvement [5][14][22][24][25].

Thirdly, Parts A and B of the checklist were merged. Originally, they were separated; the instructors had to flip back and forth when reporting on assessment results for Part B. This year, Part B was added as the final column to the checklist. This modification was made as a result of instructors' feedback, and helped make the checklist easier to use.

The fourth change was the addition of a set of instructions added as a cover page to the checklist. These directions were an attempt to illustrate the thought process instructors would go through when filling out the checklist, and were a direct result of the discussion held during a workshop designed to introduce instructors to the checklist.

The addition of the workshop was the final alteration made to the study. It was inaugurated to introduce the checklist, field any questions and/or clarify any confusions, and to encourage instructors to respond to the checklist immediately and return it to the researchers. Both confusion and the rate of return of the checklist were found to be issues in the previous iterations of the study $[10][19][20]$, and the workshop was instituted to circumvent these.

The workshop with instructors was offered in October 2013. Data were collected via the workshop and email, with Part A self-administered by instructors at the beginning and through the middle of the semester, and Part B completed once final course assessments were finalized (December to mid-January).

\section{FINDINGS AND DISCUSSION}

There were 15 instructors invited to participate during the faculty workshop. Eight instructors completed Part A of the checklist as intended for Fall 2013; and all but one of them completed Part B at the conclusion of the semester. In the end, only two instructors returned the checklist during the workshop. The remaining data were collected via email. Recruiting participation and collecting data has remained a challenge throughout the three years of the study [10][19][20], and the workshop was an attempt to alleviate this. Nonetheless, all the instructors used the workshop to discuss the checklist and ask questions as planned. Thus benefits were gained from gathering as a group to introduce the checklist, including the opportunity for faculty members to dialogue face-toface about the attributes and outcomes-based assessment practices. Hence, this process was considered a success and will be continued.

The data from the Fall 2013 iteration of the study are presented below. Readers are reminded that this is a brief look at how A Knowledge Base for Engineering, Individual and Team Work, Impact of Engineering on Society and the Environment, and Economics and Project 
Management and their associated foci and indicators are built into the distribution of eight of the engineering courses in our faculty.

\subsection{Attribute/Indicator Checklist Results}

For Part A of the checklist, instructors were asked to consider the four attributes and their associated indicators, and report on whether they were built into the associated mark distribution in their course (Full), if there was no formal process built into the mark distribution but the indicator was demonstrated (Part), or if the course did not demonstrate the indicator (None). Table 1 shows the results.

Table 1: Faculty/Course attribute assessment checklist results Fall 2013, Part A. Reported on by 8 instructors.

\begin{tabular}{|c|c|c|c|c|c|c|c|c|c|c|c|c|}
\hline \multirow{2}{*}{$\begin{array}{l}\text { Program } \\
\& \text { Number } \\
\text { of Courses }\end{array}$} & \multicolumn{3}{|c|}{$\begin{array}{l}\text { 1. Knowledge Base } \\
\text { for Eng. } \\
7 \text { indicators }\end{array}$} & \multicolumn{3}{|c|}{$\begin{array}{l}\text { 6. Ind. \& Team } \\
\text { Work } \\
16 \text { indicators }\end{array}$} & \multicolumn{3}{|c|}{$\begin{array}{l}\text { 9. Impact of Eng. on } \\
\text { Soc. \& Env. } \\
8 \text { indicators }\end{array}$} & \multicolumn{3}{|c|}{$\begin{array}{l}\text { 11. Economics \& } \\
\text { Project } \\
\text { Management } \\
18 \text { indicators } \\
\end{array}$} \\
\hline & $\overline{3}$ & $\frac{t}{0}$ & & $\bar{s}_{4}$ & $\frac{5}{0}$ & हัँ & $\overline{5}$ & $\frac{5}{0}$ & $\sum_{\tilde{z}}^{2}$ & 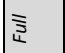 & $\frac{5}{0}$ & $\sum^{0}$ \\
\hline $\begin{array}{c}\text { BIOE } \\
2\end{array}$ & & & & & & & & & & & & \\
\hline $\begin{array}{c}\text { CIVL } \\
\mathbf{3}\end{array}$ & $5.7 \%$ & $\begin{array}{c}1 \\
14.3 \% \\
\end{array}$ & & & & & & & & & & $\begin{array}{c}4 \\
22.2 \%\end{array}$ \\
\hline & $\begin{array}{c}2 \\
28.6 \%\end{array}$ & $\begin{array}{c}3 \\
42.9 \%\end{array}$ & & & $\begin{array}{c}4 \\
25.0 \%\end{array}$ & & & $\begin{array}{c}2 \\
25.0 \%\end{array}$ & \begin{tabular}{|c|}
6 \\
$75.0 \%$
\end{tabular} & \begin{tabular}{c|}
0 \\
$0 \%$
\end{tabular} & \begin{tabular}{|c|}
4 \\
$22.2 \%$
\end{tabular} & \\
\hline $\begin{array}{l}\text { MECH } \\
2\end{array}$ & 6 & $\begin{array}{r}1 \\
14 .\end{array}$ & & & & & & & $\begin{array}{c}7 \\
87.5 \% \\
\end{array}$ & & $\begin{array}{c}5 \\
27.8 \% \\
\end{array}$ & \\
\hline $\begin{array}{c}\text { AVG. } \\
\text { indicators } \\
\text { for all } \\
\text { programs }\end{array}$ & $\begin{array}{c}4.0 \\
57.1 \%\end{array}$ & $\begin{array}{c}1.5 \\
21.4 \%\end{array}$ & \begin{tabular}{|c|}
1.5 \\
$21.4 \%$
\end{tabular} & $\begin{array}{c}.75 \\
4.7 \%\end{array}$ & $\begin{array}{c}5.5 \\
34.4 \%\end{array}$ & $\begin{array}{c}9.75 \\
60.9 \%\end{array}$ & \begin{tabular}{c|c}
1.0 \\
$12.5 \%$
\end{tabular} & $\begin{array}{c}2.25 \\
28.1 \%\end{array}$ & \begin{tabular}{|c|}
4.75 \\
$59.4 \%$
\end{tabular} & $\begin{array}{c}3.25 \\
18.1 \%\end{array}$ & $\begin{array}{c}5.25 \\
29.2 \%\end{array}$ & $\begin{array}{c}9.5 \\
52.8 \%\end{array}$ \\
\hline
\end{tabular}

Clearly, the attribute, A Knowledge Base for Engineering was assessed the most. Individual and Team Work was assessed the least, followed by Impact of Engineering on Society and the Environment, and Economics and Project Management. These three attributes had a higher percentage of indicators that were not demonstrated in their courses than percentage of indicators that were. This is consistent with the findings from the first two years of the study, where the traditional skills were more frequently assessed than the professional skills in the courses that were examined [10][19][20]. This is also a reflection of the engineering education research, which shows that not only is there less evidence of assessment of the professional skills [9][23], instructors find them more difficult to assess [1][4][8][11][12][13][26][27].

Interestingly, one instructor added two additional indicators for the Individual and Team Work attribute. They were: "Carries out individual thesis project tasks without any team members," and "May ask for help from technicians." This instructor didn't assess these indicators; merely pointed out that there were no indicators built into this attribute that demonstrated the individual component. This shows that the selection of indicators for each attribute needs revisiting with stakeholders' input.

\subsection{Evaluation Tools}

If instructors marked the indicator as demonstrated and assessed in their course (Full), then they were asked to report on the tools that were used to assess the indicator. The findings (Table 2) show that the eight instructors reported using a combination of nine different assessment tools, with assignments designated by the majority (seven), followed by final exam, which was communicated by six instructors. Notably, assignments and final exams were also the top two stated "evaluation tools" in the second year of the study [19]. This year, term tests, quizzes, labs, midterm exam, reports, projects and a final thesis document were also reported being used.

Table 2: Assessment tools used by instructors as reported in Part A. Instructors used combination of the listed tools.

\begin{tabular}{|c|c|c|}
\hline $\begin{array}{l}\text { Assessment } \\
\text { Tools }\end{array}$ & $\begin{array}{c}\text { \# of Instructors } \\
\text { Using Tool } \\
\text { (8 Instructors) }\end{array}$ & \begin{tabular}{|c|}
$\begin{array}{c}\text { Specific Description of Tools Reported } \\
\text { by Individual Instructors }\end{array}$ \\
\end{tabular} \\
\hline Assignments & 7 & $\begin{array}{ll}-\quad & \text { On-line assignments } \\
\text { Individual (IA) and } \\
\text { Team (TA) assignments }\end{array}$ \\
\hline Final exam & 6 & \\
\hline Term tests & 3 & \\
\hline Quizzes & 2 & \\
\hline Laboratories & 2 & \\
\hline Midterm exam & 2 & \\
\hline Reports & 2 & $\begin{array}{ll}\text { - } & \text { Design Report } \\
\text { - } & \text { Lab Reports }\end{array}$ \\
\hline Projects & 1 & - $\quad$ Design Project \\
\hline $\begin{array}{l}\text { Final Thesis } \\
\text { Document }\end{array}$ & 1 & \\
\hline
\end{tabular}

\subsection{Forms of Communication}

Instructors were also asked to report on how their assessments were communicated to students. They described using numerical marks (both numbers and percentages), comments (both verbal and written), rubrics and letter grades respectively (see Table 3). One instructor made a note of using both "summative and formative" assessment communication, which is language characteristic of outcomes-based assessment [5][17]. This description was not explained further. Rubrics, a tool specific to outcomes-based assessment [15][23][25], were only reportedly used by two instructors. One instructor did not explicitly fill out the category "assessment communication" despite the workshop and a subsequent conversation with the researcher explaining the checklist (data were gathered implicitly from the instructor's assessment results). This shows that the language and expectations in the checklist are perhaps not common to the instructors, demonstrating the need to build a common understanding and language for faculty-wide assessment tools. Presently, that is being explored [7][19][21]. 
Table 3: Forms of communication reported by instructors (Part A). Instructors used combination of listed categories.

\begin{tabular}{|c|c|c|}
\hline $\begin{array}{c}\text { Forms of } \\
\text { Communication }\end{array}$ & $\begin{array}{l}\text { \# Instructors } \\
\text { Using Form } \\
\text { (8 instructors) }\end{array}$ & Additional Information \\
\hline $\begin{array}{l}\text { Numerical Marks } \\
\text {-Numbers (i.e.) } \\
\text { 7/10 } \\
\text {-Percentages }\end{array}$ & 7 & $\begin{array}{l}\text { - "Numerical marks } \\
\text { translated into letter } \\
\text { grades" } \\
\text { - Section on analysis of } \\
\text { thesis topic graded } \\
\text { numerically by } 3 \text { instructors } \\
\text { and marks averaged } \\
\text { - "Percentage score" } \\
\text { - "Average mark for each } \\
\text { assessment tool" } \\
\text { - GPA (Grade Point Average) }\end{array}$ \\
\hline $\begin{array}{l}\text { Comments: } \\
\text { - Unspecified - } 2 \\
\text { - Written - } 1 \\
\text { - Verbal - } 1\end{array}$ & 4 & $\begin{array}{l}\text { - For Midterm, verbal } \\
\text { comments: "Detailed review } \\
\text { of solution during lecture" }\end{array}$ \\
\hline Rubric & 2 & $\begin{array}{l}\text { - "Informal rubric for } \\
\text { assignments and labs" }\end{array}$ \\
\hline Letter Grade & 1 & $\begin{array}{l}\text { - "Numerical marks } \\
\text { translated into letter } \\
\text { grades" }\end{array}$ \\
\hline $\begin{array}{l}\text { "Summative, } \\
\text { formative" }\end{array}$ & 1 & \\
\hline
\end{tabular}

\subsection{Expected Competency Level/Target Percentage}

Instructors were asked to report the level that indicates whether a student's knowledge, skills or behavior was competent and, new to the checklist this year, the percentage of students targeted to perform competently or better when that indicator was assessed (e.g.: 70\% of students will achieve a "C" or higher for this indicator) (see Table 4). Most instructors wrote down numerical marks or letter grades. Four instructors reported target percentage; however, there were still four instructors who did not report on this category. This highlights the need to further explain what researchers are looking for in regards to target percentage on the checklist, for despite the workshop, there was still misperception in using the instrument.

Further findings showed that four instructors reported individual assessment expectations for each indicator; others reported different assessment expectations for individual attributes. These are additional examples of outcomes-based assessment practices. One instructor did not report what the researchers intended; rather, he described the knowledge, skills and/or behaviors that his students should demonstrate to be considered competent for the indicator. Examples included: "Begin to understand when mathematical models will fail to predict behavior"; "Can apply circuit theory to electronic circuits"; "Apply knowledge as required to debug electronic system." Not only did this demonstrate outcomes-based assessment practices, these comments were made for indicators that were marked as both "Full" and "Part," indicating that even if the assessment was not summative, formative assessments of students' learning was ongoing. This was further demonstrated when the instructor indicated that he expected his students to use the formative feedback to improve their learning: "During lab and design project students receive feedback from TAs, instructor and Team members. Hopefully they integrate it into their work." Interestingly, in these data there was clear evidence of the use of outcomes-based assessment practices [17].

Table 4: Level that indicates competency and target percentage as reported by instructors (Part A.) (7 instructors reported expected competency level; 4 reported target percentage.)

\begin{tabular}{|c|c|c|}
\hline \multirow[t]{2}{*}{ Category } & \multicolumn{2}{|c|}{ Examples of Instructors' Descriptions } \\
\hline & $\begin{array}{l}\text { Expected Competency } \\
\text { Level }\end{array}$ & $\begin{array}{c}\text { Target Percentage } \\
\text { (of Students who } \\
\text { Achieve Competency) }\end{array}$ \\
\hline $\begin{array}{l}\text { Written } \\
\text { Comments }\end{array}$ & $\begin{array}{l}\text { "Begin to understand } \\
\text { when mathematical } \\
\text { models will fail to } \\
\text { predict behavior"; "Can } \\
\text { apply circuit theory to } \\
\text { electronic circuits"; } \\
\text { "Apply knowledge as } \\
\text { required to debug } \\
\text { electronic system" }\end{array}$ & $\begin{array}{l}\text {-Not recorded by } \\
\text { instructor }\end{array}$ \\
\hline \multirow{5}{*}{$\begin{array}{l}\text { Numerical } \\
\text { Marks }\end{array}$} & $-70 \%$ & - For all students \\
\hline & $-70 \%$ & $\begin{array}{l}\text { - Not recorded by } \\
\text { instructor }\end{array}$ \\
\hline & $\begin{array}{l}-60 \% \text { or higher } \\
-70 \% \text { or higher }\end{array}$ & $\begin{array}{l}-75 \% \text { of students } \\
-75 \% \text { of students } \\
\end{array}$ \\
\hline & $-50 \%$ or above & $\begin{array}{l}\text { - Not recorded by } \\
\text { instructors }\end{array}$ \\
\hline & $\begin{array}{r}-6 / 10 \\
-7 / 10 \\
\end{array}$ & $\begin{array}{l}-75 \% \text { of students } \\
-75 \% \text { of students } \\
\end{array}$ \\
\hline \multirow{5}{*}{$\begin{array}{l}\text { Letter } \\
\text { Grades }\end{array}$} & - B+ or better & - $75 \%$ of students \\
\hline & - B or better & - $100 \%$ of students \\
\hline & - B (or 70\%) or better & $\begin{array}{c}\text { - Not recorded by } \\
\text { instructor }\end{array}$ \\
\hline & $-\mathrm{C}$ & $\begin{array}{l}\text { - Not recorded by } \\
\text { instructor }\end{array}$ \\
\hline & $\begin{array}{l}-\mathrm{C}+ \\
-\mathrm{C} \\
-\mathrm{C}+ \\
-\mathrm{B} \\
\end{array}$ & $\begin{array}{l}-70 \% \text { of students } \\
-80 \% \text { of students } \\
-60 \% \text { of students } \\
-40 \% \text { of students }\end{array}$ \\
\hline
\end{tabular}

\subsection{Level that Indicates Competency and Assessment Results}

Once Part A of the checklist and final course assessments were complete, instructors were asked to report the assessment results in Part B. Seven instructors returned Part B. Table 5 is an abridged version of the data set. Findings showed that in six instructors' courses, competency levels were achieved (in all but one indicator in one course). Three of these instructors reported target percentages, which were achieved; three did not. One instructor did not report expected competency levels or target percentages. This again shows evidence of the checklist not being completed as intended, and may also speak to the larger question of instructors' lack of knowledge or familiarity with outcomes-based assessment processes overall. 
Table 5 (abridged): Level that indicates competency/target percentage and assessment results (Part B). Reported on by 7 instructors.

\begin{tabular}{|c|c|c|c|}
\hline $\begin{array}{l}\text { Attribute/Learning } \\
\text { Objective/Indicator }\end{array}$ & $\begin{array}{c}\text { Expected } \\
\text { Competency } \\
\text { Level/Target } \\
\text { Percentage }\end{array}$ & $\begin{array}{l}\text { Assessment } \\
\text { Results }\end{array}$ & $\begin{array}{c}\text { Researchers' } \\
\text { Comments }\end{array}$ \\
\hline $\begin{array}{l}\text { 1. Knowledge Base for } \\
\text { Engineering/Sciences/ } \\
\text { Demonstrates technical } \\
\text { knowledge of underlying } \\
\text { sciences pertinent to } \\
\text { engineering. }\end{array}$ & $\begin{array}{l}75 \% \text { of the } \\
\text { class with } \mathrm{B}+ \\
\text { or better }\end{array}$ & $\begin{array}{l}74.4 \% \text { of the } \\
\text { class had } \mathrm{B}+ \\
\text { or better }\end{array}$ & $\begin{array}{l}\text { Competency } \\
\text { level and } \\
\text { target } \\
\text { percentage } \\
\text { considered } \\
\text { achieved. }\end{array}$ \\
\hline $\begin{array}{l}\text { 1. Knowledge Base for } \\
\text { Engineering/ Engineering } \\
\text { Fundamentals/ } \\
\text { Demonstrates engineering } \\
\text { reasoning and appropriate } \\
\text { use of knowledge from areas } \\
\text { within and outside discipline } \\
\text { to solve engineering } \\
\text { problems. }\end{array}$ & $\begin{array}{l}70 \% \text { for all } \\
\text { students }\end{array}$ & $\begin{array}{l}70 \% \text { and } \\
\text { above for all; } \\
\text { class } \\
\text { average } \\
75.8 \%\end{array}$ & \multirow[t]{4}{*}{$\begin{array}{c}\text { Different } \\
\text { assessments } \\
\text { for each } \\
\text { indicator. } \\
\text { Achieved } \\
\text { competency } \\
\text { and target } \\
\text { percentage. }\end{array}$} \\
\hline $\begin{array}{l}\text { 11. Economics \& Project } \\
\text { Management/P.M./ } \\
\text { Establishes appropriate } \\
\text { project scope, after } \\
\text { consultation with client, } \\
\text { based on available } \\
\text { resources/ }\end{array}$ & $\begin{array}{l}\text { B or better } \\
\text { for } 100 \% \text { of } \\
\text { students }\end{array}$ & $\begin{array}{l}\text { B or better } \\
\text { for } 100 \% \text { of } \\
\text { students; } \\
\text { class } \\
\text { average } 86 \%\end{array}$ & \\
\hline $\begin{array}{l}\text { 11. Economics \& Project } \\
\text { Management/P.M./ Maps } \\
\text { out project with clear } \\
\text { milestones and delegation. }\end{array}$ & $\begin{array}{l}\text { B or better } \\
\text { for } 100 \% \text { of } \\
\text { students }\end{array}$ & $\begin{array}{l}\text { B or better } \\
\text { for } 100 \% \text { of } \\
\text { students; } \\
\text { class } \\
\text { average } 90 \%\end{array}$ & \\
\hline $\begin{array}{l}\text { 11. Economics \& Project } \\
\text { Management/P.M./ } \\
\text { Measures outcomes. }\end{array}$ & $\begin{array}{l}\text { B or better } \\
\text { for } 100 \% \text { of } \\
\text { students }\end{array}$ & $\begin{array}{l}\text { B or better } \\
\text { for } 100 \% \text { of } \\
\text { students; } \\
\quad \text { class } \\
\text { average } 90 \%\end{array}$ & \\
\hline $\begin{array}{l}\text { 1. Knowledge Base for Eng./ } \\
\text { Mathematics/Demonstrates } \\
\text { ability to create } \\
\text { mathematical expressions } \\
\text { that describe a real-world } \\
\text { problem. }\end{array}$ & $\begin{array}{l}\text { Numerical } \\
\text { grade of } 70 \% \\
\text { or better }\end{array}$ & $\begin{array}{l}\text { Avg. grade } \\
\text { from } \\
\text { relevant } \\
\text { tools }=70 \%\end{array}$ & \multirow{3}{*}{$\begin{array}{c}\text { Different } \\
\text { assessments } \\
\text { for each } \\
\text { indicator. } \\
\text { Achieved } \\
\text { competency } \\
\text { level in all but } \\
\text { one indicator; } \\
\text { no target } \\
\text { percentage. }\end{array}$} \\
\hline $\begin{array}{l}\text { 1. Knowledge Base for Eng./ } \\
\text { Sciences/Demonstrates } \\
\text { technical knowledge of } \\
\text { underlying sciences } \\
\text { pertinent to engineering. }\end{array}$ & $\begin{array}{l}\text { Numerical } \\
\text { grade of } 70 \% \\
\text { or better }\end{array}$ & $\begin{array}{l}\text { Avg. grade } \\
\text { from } \\
\text { relevant } \\
\text { tools }=83 \%\end{array}$ & \\
\hline $\begin{array}{l}\text { 1. Knowledge Base for Eng./ } \\
\text { Eng. } \\
\text { Fundamentals/Understands } \\
\text { facts and concepts relevant } \\
\text { to a process or system. }\end{array}$ & $\begin{array}{l}\text { Numerical } \\
\text { grade of } 70 \% \\
\text { or better }\end{array}$ & $\begin{array}{l}\text { Avg. grade } \\
\text { from } \\
\text { relevant } \\
\text { tools }=62 \%\end{array}$ & \\
\hline
\end{tabular}

\section{CONCLUSIONS AND NEXT STEPS}

The faculty attribute assessment study is a longitudinal study with the aim to explore how the 12 CEAB Graduate Attributes are manifest and measured in some of the engineering courses in the Faculty of Engineering at the University of Manitoba. The findings from this study have afforded us a vision of where and how the graduate attributes are taught and assessed in our engineering programs, and generally demonstrated that the traditional skills are more commonly assessed than the professional skills. Some insight has been gained into the use of outcomes-based assessment practices within the faculty. Additionally, the need to continue the work to develop a common language and understanding of outcomes-based assessment practices through the development and use of outcomes-based assessment tools has been highlighted.

The checklist used in this study was one such assessment tool. Over the three-year iteration, the tool was revised in an effort to employ the feedback of participating instructors, and in an attempt to clarify and develop a common language and understanding of the assessment practices we were investigating. The checklist was also amended to further explore assessment practices that were revealed through the examination of the data. Expected competency levels and target percentages of students anticipated to achieve these competencies is one such example of a category reflective of an outcomesbased assessment practice that evolved out of the recurrent enhancement of the checklist.

That being said, the checklist in its present form will now be retired. This effort, in conjunction with other assessment initiatives across the faculty, has identified the need to further develop the indicators for each of the attributes. New work is being undertaken to create a set of rubrics that will, among other things, be a foundation for a new set of assessment tools used to explore outcomesbased assessment in the faculty. Nevertheless, the findings from this study have laid the groundwork for future work. We have been provided with an overview of how the 12 graduate attributes are manifest and measured in our courses, gained some understanding of the presence of outcomes-based assessment practices in the faculty, and reflected on the process to develop an alternative way to obtain data from instructors. The resulting workshop method is one that we will continue to refine.

Reflecting on this study has shown that despite the difficulties in trying to collect data from instructors who are already extremely busy, or who may not yet entirely see the value of such an exercise, immense benefits have been gained. We are now in the position where further development and improvement of our engineering curriculum will fully demonstrate an outcomes-based engineering education protocol.

\section{Acknowledgements}

The authors would like to thank the following instructors for their work in helping us obtain these data: J.P. Burak, Nazim Cicek, David Levin, Peter Rasmussen, Jonathan Regehr, Mohamed Issa, Hassan Soliman, Vijay Chatoorgoon, and Douglas Thomson. This work would not have been possible without their valuable input. This research study was made possible through funding from the University of Manitoba Faculty of Engineering Startup Grant to Dr. Ingram, and the University of Manitoba 
Graduate Fellowship (UMGF) and Manitoba Graduate Scholarship (MGS) granted to Jillian Seniuk Cicek.

\section{References}

[1] Brock E. Barry and Matthew W. Ohland, "Applied ethics in the engineering, health, business, and law professions: A comparison," Journal of Engineering Education, vol. 98, no. 4, pp. 377-388, 2009.

[2] William Bishop, Oscar Nespoli, and Wayne Parker, "Rubrics for accreditation and outcomes assessment in engineering capstone projects," in Proc. 2012 Canadian Engineering Education Association Conf., CEEA12, (Winnipeg, MB; 17-21 June 2012), 7 pp., 2012.

[3] Ralph O. Buchal, "Which type of design project is best: narrow and detailed or broad and conceptual?," in Proc. 2012 Canadian Engineering Education Association Conf., CEEA12, (Winnipeg, MB; 17-21 June 2012), 6 pp., 2012.

[4] Anne Colby and William M. Sullivan, "Ethics teaching in undergraduate engineering education," Journal of Engineering Education, vol. 97, no. 3, pp. 327-338, 2008.

[5] Amy Driscoll and Swarup Wood, Developing Outcomesbased Assessment for Learning-centered Education: A Faculty Introduction. Sterling, VA: Stylus, 2007, 275 pp. \{ISBN: 978 I 579221959$\}$

[6] Daniel Dupuis and Christian St. Pierre, "Assessing graduate attributes as described by CEAB: An exploratory study in a first year design course," in Proc. CEEA Canadian Engineering Education Conf., CEEC13, Michel Perrier and Sylvie Dore (eds.) (Montreal, QC; 17-20 June 2013), 7 pp., 2013.

[7] Ken Ferens, Jillian Seniuk Cicek, Nariman Sepehri, Witold Kinsner, J.P. Burak, Anne Parker, Dean McNeill, Douglas Ruth, Ian Jeffrey, Norma Godavari, and Sandra Ingram, "Industry Forum III: Towards a common language," in Proc. CEEA Canadian Engineering Education Conf., CEEC14, Sean Maw and Marjan Eggermont (eds.) (Canmore, AB; 811 June 2014), 7 pp., 2014.

[8] James H. Hanson and Julia M. Williams, "Using writing assignments to improve self-assessment and communication skills in an engineering statics course," Journal of Engineering Education, vol. 97, no. 4, pp. 515-529, 2008.

[9] Matthew A. Holsapple, Donald D. Carpenter, Janel A. Sutkus, Cynthia J. Finelli, and Trevor S. Harding, "Framing faculty and student discrepancies in engineering ethics delivery," Journal of Engineering Education, vol. 101, no. 2, pp. 169-186, 2012.

[10] Sandra Ingram, Jillian Seniuk Cicek and Nariman Sepehri, "The Attribute assessment process at the University of Manitoba," in Proc. CEAA Canadian Engineering Conf., CEEC12, (Winnipeg, MB; 17-21 June 2012), 7 pp., 2012.

[11] Scott Jiusto and David DiBiasio, D., "Experiential learning

CEEA14; Paper 032 environments: Do they prepare our students to be selfdirected, life-long learners?," Journal of Engineering Education, vol. 95, no. 3, pp. 195-204, 2006.

[12] David H. Jonassen, Demei Shen, Rose M. Marra, YoungHoan Cho, Jenny L. Lo and Vinod Lohani, "Engaging and supporting problem solving in engineering ethics," Journal of Engineering Education, vol. 98, no. 3, pp. 235-254, 2009.

[13] Michael C. Loui, "Assessment of an engineering ethics video: Incident at Morales," Journal of Engineering Education, vol. 95, no. 1, pp. 85-91, 2006.

[14] Jack McGourty, Catherine Sebastian, and William Swart, "Developing a comprehensive assessment program for engineering education," Journal of Engineering Education, vol. 87, no. 4, pp. 355-361, 1998.

[15] Barbara M. Olds, Barbara M. Moskal, and Ronald L. Miller, "Assessment in engineering education: Evolution, approaches and future collaborations, Journal of Engineering Education, vol. 94, no. 1, pp. 13-25, 2005.

[16] Honor Passow, "Which ABET competencies do engineering graduates find most important in their work?," Journal of Engineering Education, vol. 101, no. 1, pp. 95$118,2012$.

[17] Gloria M. Rogers, "EC2000 and measurement: How much precision is enough?," Journal of Engineering Education, vol. 89, no. 2, pp. 161-166, 2000.

[18] Katherine Scales, Christi Owen, Subodh Shiohare, and Michael Leonard, "Preparing for program accreditation review under ABET engineering criteria 2000: Choosing outcome indicators," Journal of Engineering Education, vol. 87, no. 3, pp. 207-210, 1998.

[19] Jillian Seniuk Cicek, Sandra Ingram, and Nariman Sepehri, (In press) "Outcomes-Based Assessment in Action: Engineering Faculty Examine Graduate Attributes in their Courses," International Journal of Engineering Education, 2014.

[20] Jillian Seniuk Cicek, Sandra Ingram, and Nariman Sepehri, "The attribute assessment process at the University of Manitoba: Year two," in Proc. CEEA Canadian Engineering Education Conf., CEEC13, Michel Perrier and Sylvie Dore (eds.) (Montreal, QC; 17-20 June 2013), 7 pp., 2013.

[21] Jillian Seniuk Cicek, Sandra Ingram, Nariman Sepehri, J.P Burak, Paul Labossiere, Danny Mann, Douglas Ruth, Anne Parker, Ken Ferens, Norma Godarvi, Jan Oleszkiewicz, and Aidan Topping, "Rubrics as a Vehicle to Define the Twelve CEAB Graduate Attributes, Determine Graduate Competencies, and Develop a Common Language for Engineering Stakeholders," in Proc. CEEA Canadian Engineering Education Conf., CEEC14, Sean Maw and Marjan Eggermont (eds.) (Canmore, AB; 8-11 June 2014), 6 pp., 2014. 
[22] Joseph Shaeiwitz, "Outcomes assessment in engineering education," Journal of Engineering Education, vol. 85, no. 3, pp. 239-246, 1996.

[23] Larry J. Shuman, Mary Besterfield-Sacre and Jack McGourty, "The ABET "professional skills" - can they be taught? Can they be assessed?," Journal of Engineering Education, vol. 94, no. 1, pp. 41-55, 2005.

[24] Neelam Soundarajan, "Preparing for accreditation under EC 2000: An experience report," Journal of Engineering Education, vol. 91, no. 1, pp. 117-123, 2002.

[25] Joni E. Spurlin, Sarah A. Rajala, and Jerome P. Lavelle, Designing Better Engineering Education Through Assessment. Sterling, VA: Stylus, 2008, 360 pp. [ISBN: $978-$ I-57922-212-3\}

[26] Bugrahan Yalvac, H. David Smith, John B. Troy, and Penny Hirsch, "Promoting advanced writing skills in an upper level engineering class," Journal of Engineering Education, vol. 96, no. 2, pp. 117-128, 2007.

[27] Carman R. Zafft, Stephanie G. Adams, and Gina S. Matkin, "Measuring leadership in self-managed teams using the competing values framework," Journal of Engineering Education, vol. 98, no. 3, pp. 273-282, 2009.

\section{APPENDIX A: Instructions for Faculty/Course Attribute Checklist 2013-2014}

\section{CHECKLIST Annotated Directions}

\section{ATTRIBUTES}

- A Knowledge Base for Engineering

- Individual and Team Work

- Impact of Engineering on Society and Environment

- Economics and Project Management

Ask Yourself:

Attribute (is this attribute built into my course?) - Yes or No?

If yes:

Indicator (is this indicator built into my course?) - Yes or No?

If yes, check either:

Full (teach and assess) or Part (teach but don't assess)?

If Full, record:

- Assessment tool(s)

- Assessment communication

- Expected competency level/target percentage

\section{PART A:}

Please reflect on your teaching of (course name) and assess the course to determine whether the following attributes and their associated indicators are built into your course. (Note: You do NOT need to check each indicator, only those that apply to your course.) There are empty boxes for additional indicators should you have any.

\section{Legend}

Full

Part

None

If you checked "Full," please also indicate the assessment tool(s), assessment communication, and expected competency level/target percentage:

Assessment Tool(s)

Assessment Communication

Expected Competency Level/Target Percentage

\section{PART B:}

For those attributes and associated indicators that you formally assessed (you checked "Full" in Part A), please report on the assessment results (e.g. numerical marks, letter grades, mark sheet/rubric levels, written comments, etc.) for the class as related to your indicated expected competency level/target percentage (e.g.: $70 \%$ of students received a "C" or higher for this indicator. 